\title{
Electromagnetic Radiations: A Possible Impact on Population of House Sparrow (Passer Domesticus)
}

\section{Virendra Abaji Shende ${ }^{1}$, Kishor G. Patil ${ }^{2 *}$}

\author{
${ }^{1}$ K. Z. S. Science College, Bramhani-Kalmeshwar, Dist- Nagpur (M.S.), INDIA \\ ${ }^{2}$ Department of Zoology, Institute of Science, R. T. Marg Nagpur (M.S.) INDIA \\ *Corresponding Contact: \\ Email: drkgpatil@gmail.com
}

\begin{abstract}
The modern world is a full of contamination of radiofrequency (RF), "electrosmog" in the urban centers especially after the rapid introduction of mobile telecommunications systems. The aim of this study is to determine the impact on population of house sparrow, Passer domesticus by electromagnetic radiation (microwaves) from phone antennae. By monthly monitoring in urban and rural area, it is found that the population of house sparrow is declining in the urban area, where cell phone towers are more as compared to the rural area in every season.
\end{abstract}

Key words

Electromagnetic radiations, phone antennae, house sparrow, Passer domesticus

\section{INTRODUCTION}

India is one of the fastest growing mobile telephony industries in the world. It is estimated that by 2013, 1 billion plus people will be having cell phone connection in India. To support this growth of cell phone subscriber in the country, there has also been a tremendous growth of infrastructure in the form of mobile phone towers. Today, in absence of any policy on infrastructure development and location of cell phone towers, large numbers of mobile phone towers are being installed in a haphazard manner across urban and rural areas including other sparsely populated areas in India. These cell phone towers emit electromagnetic radiations.

The electromagnetic radiations (EMR) are extensively used in modern communication and technology. Radio waves and microwaves are forms of electromagnetic energy that are collectively described by the term "radiofrequency" or "RF". Electromagnetic radiation is generally described as a self-propagating wave in space with electric and magnetic components. The modern word is used to define the electromagnetic radiation contamination caused by mobile communication base stations. GSM base stations emit 
electromagnetic fields at high frequencies in the 900 and $1800 \mathrm{MHz}$ range (= downlink frequency bands), pulse modulated in low frequencies. These pulsating waves of 900 $\mathrm{MHz}$. for analog and $1800 \mathrm{MHz}$. for digital transmission is known to penetrate nervous systems of living beings. The transmission towers are based on the electromagnetic waves, which over prolonged usage have adverse impacts on humans as well as on other fauna. The adverse effects of electromagnetic radiation from mobile phones and communication towers on health of human beings are well documented today.

Recent evidence suggests that wildlife near mobile phone antennas may also be affected by radio frequency radiation. These studies show that animals and birds, living within 200 $\mathrm{m}$ of a cell phone antenna are adversely affected. Radio frequency exposure has also been suggested for the decline of the European house sparrow (De Pomerai et al., 2003) and the potential bee colony collapses (Dutta etal., 1989) in recent years. A house sparrow is most preferred indicator species of urban ecosystems. A stable house sparrow population indicates a healthy ecosystem for human beings in terms of air and water quality, vegetation and other parameters of habitat quality. Whereas, a declining population of the bird provides a warning that the urban ecosystem is experiencing some environmental changes unsuitable for human health in the immediate future (Kumar, 2010).

Recent declines in the house sparrow (Passer domesticus) population have been reported in the United Kingdom (U.K.) and in several western European countries. A massive decrease has led to almost complete extinction in some urban centres; for example, there was a 71\% decline in London from 1994-2002 (Raven etal, 2002). Urban bird populations in south east England seem to be declining more rapidly than suburban or rural populations (Crick etal, 2002); there have been dramatic declines, almost to the point of extinction, in Glasgow, Edinburgh, Hamburg, and Ghent, although the species has actually increased in Scotland and Wales; in 2002, the house sparrow was added to the Red List of U.K. endangered species (Summers-Smith, 2003).

Here, we reported the results of a preliminary study that explored putative effects of electromagnetic radiation emitted by cell phone towers on the population of Passer domesticus in the Kalmeshwar region.

\section{MATERIAL AND METHODS}

In the Kalmeshwar region, (Nagpur district, Maharashtra) we were monitored the populations of the Passer domesticus (House sparrow) round the year from July 2011 to June 2012. We were surveyed in Kalmeshwar and nearby area (Dahegaon, Dorli, (Bha), Khairi (La), Parsodi, Zunki, Bramhani, Waroda, Ghorad, Ubali, Ubali Peth, Savangi, Selu, Shahajapur, Pipla). Sampling was performed on morning between 5.15 a.m. and 11.15 a.m. and on evening between 3.15 p.m. to 7.15 p.m., when they were the most active and conspicuous. Samplings are done on Sunday, since there is less traffic and noise. On same area we visited once in a month. The samplings were done from center of cell towers to approx. 300 meters away, in two different routes approximately 628 meters and 1256 meters circumference. Direct observations and species noting were made by walking along the roads, tracks, nearby fields, water bodies, squares, parks, and trees. In each area, we counted all sparrows that were heard or seen, without differentiating the birds by sex or age. We adopted a Line Transects Method (Gregory, 2004) to study the population pattern in different localities. The correlation is statistically correlated by Pearson's productmoment correlation test, using statistical software " $R$ ". 
Table 1: Showing Number of Radiofrequency Towers with Mean Population, Standard Deviation and Standard Error Mean of Passer Domestics.

\begin{tabular}{|r|l|c|c|c|c|}
\hline \multicolumn{1}{|c|}{ S. N. } & Area / Villages & RF Towers & Mean Popu. & SD & SEM \\
\hline 1 & DAHEGAON & 2 & 152.58 & 22.50 & \pm 5.81 \\
\hline 2 & DORLI (BHA) & 2 & 164.33 & 14.78 & \pm 3.82 \\
\hline 3 & KHAIRI (LA) & 1 & 184.75 & 22.99 & \pm 5.94 \\
\hline 4 & KALMESHWAR & $\mathbf{6}$ & $\mathbf{1 2 8 . 0 0}$ & $\mathbf{1 8 . 6 5}$ & \pm 4.82 \\
\hline 5 & PARSODI & 2 & 159.67 & 20.86 & \pm 5.39 \\
\hline 6 & ZUNKI & 1 & 191.58 & 20.78 & \pm 5.36 \\
\hline 7 & BRAMHANI & 2 & 155.33 & 20.63 & \pm 5.33 \\
\hline 8 & WARODA & 2 & 162.50 & 23.86 & \pm 6.16 \\
\hline 9 & GHORAD & 1 & 189.00 & 20.69 & \pm 5.34 \\
\hline 10 & UBALI & 2 & 160.83 & 24.60 & \pm 6.35 \\
\hline 12 & SAVANGI & 1 & 167.17 & 27.46 & \pm 7.09 \\
\hline 13 & SELU & 1 & 154.00 & 21.13 & \pm 5.46 \\
\hline 15 & PIPLA & 2 & 156.92 & 17.02 & \pm 4.39 \\
\hline
\end{tabular}

Table 2: Showing Pearson's product-moment correlation test with population of Passer domesticus and the number of cell phone towers

\section{Pearson's product-moment correlation test}

Use of $\mathrm{t}$ - test to observe the significance of correlation coefficient

$\mathrm{H}_{0}: \rho=\mathbf{0}$ against $\mathrm{H}_{1}: \rho \neq \mathbf{0}$;

$\mathrm{H}_{0}$ and $\mathrm{H}_{1}=$ Hypothesis $\mathbf{0}$ and Hypothesis;

Accept $\mathrm{H}_{0}=$ Variables are not correlated to each other;

Reject $\mathrm{H}_{0}=$ Variables are significantly correlated;

$\boldsymbol{\rho}=$ Population correlation coefficient; $\quad \mathbf{t}=$ Student's ' $\mathrm{t}$ ' test;

$\mathbf{d f}=$ degree of freedom $=11$ ； Table value for $\mathbf{t}$ - test $=\mathbf{3 . 1 0 6}$;

Level of significance $=\mathbf{1} \%$

\begin{tabular}{|l|l|c|r|}
\hline S.N. & Correlation between variable & Parameter & \multicolumn{1}{c|}{ Readings } \\
\hline \multirow{3}{*}{$\mathbf{1}$} & \multirow{3}{*}{$\begin{array}{l}\text { Population of Passer domesticus with } \\
n n n y y\end{array}$} & $\mathbf{t}$ & $(-) 4.1153$ \\
\cline { 3 - 4 } & number of cell phone towers & $\mathbf{d f}$ & 0.001714 \\
\cline { 3 - 4 } & & $\mathbf{9 5 \%}$ conf. & -0.9304369 \\
\cline { 3 - 4 } & & cor & -0.3986505 \\
\hline
\end{tabular}

Graph 1: Showing Total Population of Passer domesticus round the year in the Kalmeshwar region

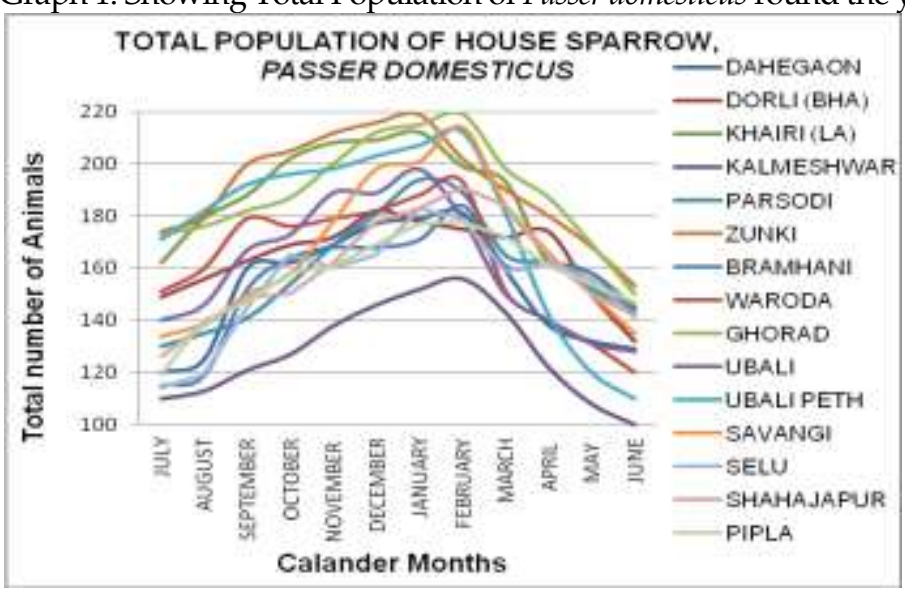


Graph 2: Showing Relationship between Mean Population (with SEM) of Passer domesticus with number of Radio-Friquency towers in the Kalmeshwar region

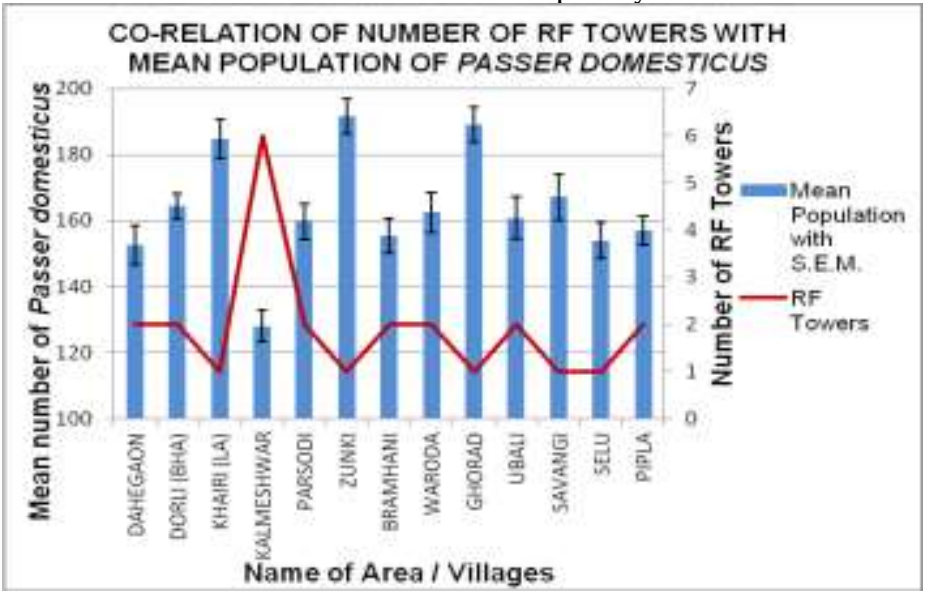

Graph 3: Showing Relationship between dispersal of Population of Passer domesticus with distance (in Meter) from towers in the Kalmeshwar region

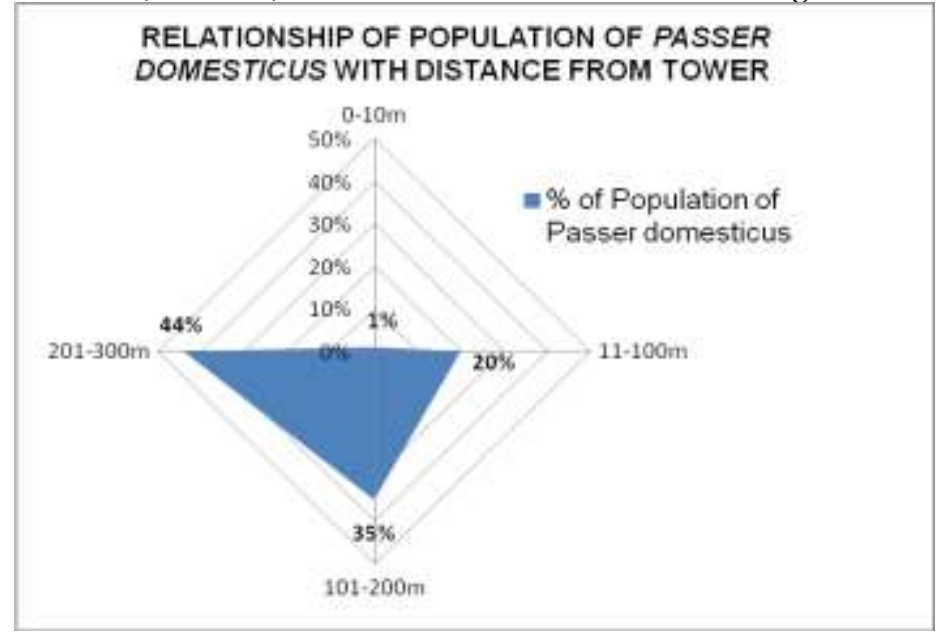

\section{OBSERVATIONS AND Discussions}

There are three distinct seasons in this region of India: Summer (March-May), Rainy season (June-October), and Winter (November- February). The population of Passer domesticus in town Kalmeshwar and nearby area is varied cyclically throughout the year. The number of sparrows increased from July to February and then starts decreasing from February to June. The maximum number of Passer domesticus is observed during the month of January and February and the minimum number during the month of May and June in Kalmeshwar as well as in other villages (Graph-1). Mating in house sparrow occurs throughout the breeding cycle, i.e., from March to early August (Franklin, 2007). However, in the North India, this species breeds during March-June (Jansen, 1983), March to July (Chopra etal, 2012), in central India continuing till September-October and in southern India throughout the year (Jansen, 1983). More number of house sparrows are observed in the months of January and February due to above breeding period and then the number of house sparrows goes on decreasing 
because of high death rate of youngones*. In Valladolid, Spain, it is noticed that the number of house sparrows varied cyclically throughout the year. The number of sparrows increased towards a midwinter peak and then decreased again through the spring (Balmori and Hallberg, 2007a; Balmori and Hallberg, 2007b).

Three peaks in population of Passer domesticus are clearly seen in Graph-2, which shows maximum number of animals are observed in Khairi (La), Zunki and Ghorad. Lowest number of animals is noticed in Kalmeshwar, while the intermediate peaks are observed in Dahegaon, Dorli (Bha), Parsodi, Bramhani, Waroda, Ubali, Savangi, Selu and Pipla. In Khairi (La), Zunki and Ghorad noticed only one tower each and the population of animals shows high peaks. In Savangi and Selu although there is a single tower each, still the population of animals does not show high peaks. In Dahegaon, Dorli (Bha), Parsodi, Bramhani, Waroda, Ubali, Savangi, Selu and Pipla noticed two towers each and the population of animals shows intermediate peaks. In the town Kalmeshwar the number of towers is six and population of animals shows lowest peak (Graph-2).

Above finding are similar with a gradual disappearance of sparrows in the most contaminated (EMF) streets and squares. Goyal (Goyal, 2005) was found that house sparrows do not inhabit dense forest and are more abundant in agricultural field as compared to residential colony. The number of sparrows was decreased in the city center and increasing in the outskirts. The sparrows were disappeared at several points and streets of the city containing high electromagnetic contamination and increase to the low contaminated areas (Goyal, 2005).

The intensity of manmade electromagnetic radiation has become so ubiquitous and it is now increasingly being recognized as a form of unseen and insidious pollution that might perniciously be affecting life forms in multiple ways (Balmori, 2005; Balmori, 2006; Balmori, 2009; Tanwar, 2006). The number of Telecommunication Masts in big cities and the use of mobile phones, in general, are much greater than in small towns. Big cities usually have more electromagnetic contamination, but this differs between areas (vicinity of Masts) and because of this the decline of these birds does not happen to the same degree in different parks or neighbourhoods or different cities. Small towns usually have the telecommunication masts located away from the urban centre because this is sufficient to maintain the coverage. Because of this birds are less affected in small towns and villages than the cities (Goyal, 2005). Similar findings are observed in present observations that the number of birds in villages is more than that of town Kalmeshwar. But in villages Selu and Savangi population of birds decreases as compared to the other villages where only single tower is installed. It is justified that, these villages are nearer to the MIDC area Kalmeshwar, this might be the effect of pollution so that such types of findings are noticed. There was a definite decline in their number over the last decade because of loss of nesting sites, food sources, pollution, diseases and increase in predators (Summers-Smith, 1988a; SummersSmith, 1988b; Summers-Smith, 1988c; Summers-Smith, 1999; Dandapat etal, 2010).

It is found that from 0-10 meter, 11-100 meter, 101-200 meter and 201-300 meter approximately $1 \%, 20 \%, 35 \%$ and $44 \%$ population reside in every month (Graph-3). Because at 1 meters, 100 meters and 500 meters cell tower antennas transmit 79,600,000 $\mu \mathrm{W} / \mathrm{m} 2,7,960 \mu \mathrm{W} / \mathrm{m} 2$ and 318 $\mu \mathrm{W} / \mathrm{m} 2$ power density respectively. These power density values are for a single carrier and a single operator. If multiple carriers are being used and multiple operators are present on the same roof top or tower, then the above values will increase manifold (Kumar, 2010). Therefore, there is a flow of sparrows moving from high to low contaminated areas (Goyal, 2005). Nesting, breeding, and hatching in White storks success were significantly reduced for those 
birds near the cell phone antenna. The number of young per pair for nests near the antenna was significantly lower than for those farther away (0.86 vs. 1.6, 50\% decrease, $\mathrm{P}=0.001)$ (Havas, 2007); these observations are similar with the present survey.

The population of Passer domesticus, in Waroda, Ubali and Savangi, shows more fluctuation (SEM) than that of population of Dorli (Bha). The correlation between population of Passer domesticus and number of RF towers shows that, the population of Passer domesticus is decreases with increase in number of RF towers (Table-1). This correlation is statistically correlated by using Pearson's product-moment correlation test, where number of Passer domesticus is significantly correlated with number of cell phone towers at $95 \%$ level of confidence and $1 \%$ level of significance (Table-2). Similar observations in house sparrow are reported by (Balmori, 2009; Summers-Smith, 1988b; Summers-Smith, 1988c; Everaert. and Bauwens, 2007; Rajashekher and Ventkanteha, 2008). The logarithmic regression of the mean bird density vs. field strength was reported in house sparrow (Balmori and Hallberg, 2007a).

A marked decline of sparrow population has been reported from different countries over the globe particularly in urban habitats including Berlin, Brussels, Spain and Dublin, Western Europe, Dutch urban centres and the United Kingdom (Raven etal, 2002; Crick etal, 2002; Summers-Smith, 2003; Balmori and Hallberg, 2007a; Summers-Smith, 1999; De Laet, 2004). The House Sparrow is already Red List of Netherlands, where it has a decline over $50 \%$ of its total population in the last 25 years of the 20th century. In UK, a massive decrease in the House Sparrow population; has led to almost complete extinction in some urban centres like London, where there was a 71\% decline from 1994 to 2002 (Raven etal, 2002; Crick etal, 2002). As far as India is concerned, the survey reports on the occurrences of house sparrow at different places have shown a considerable decline in its population along urban gradient (Rajashekher and Ventkanteha, 2008; Denis, 2005; Khera etal, 2010; Bhattacharya etal, 2010; Ghosh etal, 2010).

Electromagnetic radiation may be responsible, either by itself or in combination with other factors, for the observed decline of the sparrows in European cities (Balmori, 2009; Balmori and Hallberg, 2007a). Research in Spain proved that the microwaves released from these towers are harmful to House Sparrows and the increase in the concentration of microwaves results into decrease in House Sparrow populations (Everaert. and Bauwens, 2007; Fernie and Reynolds, 2005). Reproductive and co-ordination problems and aggressive behavior has also been observed in birds such as sparrows. General methodology used for such study was, from each area, all sparrows were counted in addition to the mean electric field strength. The electromagnetic radiations are being associated with the observed decline in the population of sparrow in London and several other European cities (Balmori and Hallberg, 2007a; Balmori, 2003; Balmori, 2005; Balmori, 2009; Everaert and Bauwens, 2007; Crick etal, 2002).

In similar studies in India, population of Passer domesticus was found fast disappearing from areas contaminated with electromagnetic waves arising out of increased number of cell phones, in Bhopal, Nagpur, Jabalpur, Ujjain, Gwaliar, Chhindwara, Indore and Betul (Dongre and Verma, 2009).

\section{CONCLUSION}

By above observations and discussions it is concluded that, the electromagnetic signals are directly or indirectly associated with the decline in the house sparrow population in Kalmeshwar and nearby areas. 


\section{REFERENCES}

Balmori, A, 2005. Possible Effects of Electromagnetic Fields from Phone Masts on a Population of White Stork (Ciconia ciconia). Electromagn Biol Med, 24: 109-119.

Balmori, A. 2003. The effects of microwaves on the trees and other plants. Valladolid, Spain, 2003b. Available online at buergerwelle. de.

Balmori, A. 2006. The incidence of electromagnetic pollution on the amphibian decline: Is this an important piece of the puzzle? Toxicological and Environmental Chemistry, 88: 287-299.

Balmori, A. 2009. Electromagnetic pollution from phone masts. Effects on wildlife. Pathophysiology, 16: 191-199.

Balmori, A. and Hallberg O. 2007a. The Urban Decline of the House Sparrow (Passer domesticus): A Possible Link with Electromagnetic Radiation. Electromagnetic Biology and Medicine, 26: 141-151.

Balmori, A. and Hallberg O. 2007b. Wall clining: Energy saving by the house sparrow, Passer domesticus, Ibis, 126(1):72-74.

Bhattacharya, R., Roy R., Ghosh S. and Dey A. 2010. Observations on house House Sparrow (Passer domesticus) in Delhi, India. Urban Ecosystem, 13(1):111-116.

Chopra, G., Kumar A., and Rai D. 2012. Clutch Size and Egg Morphometric Parameters of House Sparrow, Passer domesticus (Linnaeus, 1758) in District Kurukshetra, Haryana (India), Researcher; 4(6), 56-61.

Crick, H., Robinson, R., Appleton, G., Clark, N., Rickard, A. 2002. Investigation into the causes of the decline of starlings and Passer domesticus in Great Britain. BTO Research Report N_290. Department for Environment, Food and Rural Affairs (DEFRA). London.

Crick, R., Noble D., Robinson J., Brown A., Hughes J, Procter D, Gibbons D and Galbraith C. 2002. The population status of birds in the United Kingdom, Channel Islands and Isle of Man: An analysis of conservation concern. British Birds, 95:410-448.

Dandapat, A., Banerjee D. and Chakraborty D. 2010. The case of the Disappearing House Sparrow (Passer domesticus indicus). Veterinary World, 3(2): 97-100.

De Laet, J. 2004. Ligue Royale Belgue pour la Protection des Oiseaux avec l'Université de Gand, 2004, <http://www.protectiondesoiseaux.be/ content/view/801/74/> (Accessed on May 20, 2008).

De Pomerai, et al. 2003. RFR damages proteins at $0.015-0.020 \mathrm{~W} / \mathrm{kg}$. (Compare to $0.08 \mathrm{~W} / \mathrm{kg}$ FCC Guideline.)

Denis, J. 2005. Distribution, abidance and dynamic of house sparrow (Passer domesticus) in Berlin. Intern. Stud. Sparrow, 32:15-23.

Dongre, S. and Verma R. 2009. Effect of Cell Phone Radiation on Gauriya Sparrows Passer domesticus. Shodh, Samiksha aur Mulyankan, Vol. II, Issue-7.

Dutta, et al. 1989. Reported an increase in calcium efflux in cells after exposure to RFR at $0.005 \mathrm{~W} / \mathrm{kg}$. Calcium is an important component of normal cellular functions. (Compare to $0.08 \mathrm{~W} / \mathrm{kg}$ FCC Guideline.)

Everaert, J. and Bauwens D. 2007. A possible effect of electromagnetic radiation from mobile phone base stations on the number of breeding House Sparrows (Passer domesticus), Electromagn. Biol. Med. 26, 63-72.

Fernie, K. and Reynolds S. 2005. The effects of electromagnetic fields from power lines on avian reproductive biology and physiology: a review. Journal of toxicology and environmental health, part b, 8:127-140.

Franklin, K. 2007. The reproductive pattern amongs sparrow. Audubon naturalist society,12-27.

Ghosh, S, KiHyun K. and Bhattacharya R. 2010. A survey on house sparrow Environmental Science, Kalyani University: 147-152.

Goyal M. 2005. Preliminary survey of house sparrow ( Passer domesticus) in three areas of Haridwar, Uttrakhand. M.Sc. thesis, Gurukul Kangri University, Haridwar, India, 1-27. 
Gregory, R. D., Gibbons D. W., and Donald P. F. 2004. Bird census and survey techniques.

Havas, M. 2007. Analysis of Health and Environmental Effects of Proposed San Francisco Earthlink Wi-Fi Network. Environmental and Resource Studies, Trent University, Peterborough, Ontario, Canada, K9j $7 \mathrm{~b} 8$.

Jansen, R. R. 1983. "House Sparrows build roost nests". The Loon 55: 64-65. ISSN 0024-645X.

Khera, N, Das A, Srivastava S and Jain S. 2010. Habitat wise distribution of the house sparrow, Passer domesticus; 5(3):16-19.

Kumar, G. 2010. Report on Cell Tower Radiation. Submitted to Secretary, DOT, Delhi

Rajashekher S and Ventkanteha M 2008. Occurrence of home sparrow, Passer domesticus indicus and around Banglore. Current science, 94(4): 446-449.

Raven, M., Noble, D., Baillie, S. 2002. The breeding bird survey 2002). BTO Research Report 334. British Trust for Ornithology, Thetford.

Summers-Smith, J. 1988a. The Sparrows. illustrated by Robert Gillmor. Calton, Staffs, England: T. and A. D. Poyser, 1-11.

Summers-Smith, J. 1988b. The Sparrows, Poyser, Calton. Møller, A.P. 1987. Variation in badge size in male House Sparrows Passer domesticus - evidence for status signalling. Animal Behaviour, 35:1637-1644.

Summers-Smith, J. 1988c. The house sparrow. Colhis, London, UK: 1-18.

Summers-Smith, J. 1999. The Adaptive House Saprrow, Notorins, 21(1):88.

Summers-Smith, J. 2003. The decline of the House Sparrow: a review. Brit. Birds, 96:439-446.

Tanwar, V.S. 2006. Living dangerously in Indian cities: An RF radiation pollution perspective. Proceedings of the 9th INCEMIC, p. 458-466. Bangalore. 